\title{
DE STRIJD DER GENERALE BROUWERS VAN HOLLAND OM HET GISTMONOPOLIE.
}

De eerst om de twee, later om de vier jaar gehouden vergaderingen der droogscheerders ${ }^{1}$ ) zijn tijdens de Republiek in de provincie Holland niet het eenige voorbeeld geweest van een geregeld verband tusschen vakgenooten-industrieelen uit verschillende steden van het gewest. Van 1662 tot 1816 zijn met eenige onderbrekingen de brouwers uit de meeste șteden van Holland geregeld jaarlijks in Den Haag samengekomen, soms zelfs meer dan eenmaal per jaar, wanneer er belangrijke spoedeischende zaken te behandelen waren. Terwijl we betreffende de bijeenkomsten en het optreden der Hollandsche brouwers in de jaren voor 1700 slechts allerlei verspreide gegevens bezitten, zooals verslagen van de Delftsche afgevaardigden aan hun confrerie ${ }^{2}$ ), requesten en memories bij de Staten van Holland ingediend, briever enz., vinden wij van de van 1700 tot en met 1805 gehouden vergaderingen de notulen in het ten gemeente-archieve van Delft berustende Resolutie-Boek van de Generale Brouwers van Holland ${ }^{3}$ ).

Het geheele - zeer omvàngrijke - materiaal betreffende de' Generale Brouwers geeft ons een niet heel rooskleurig beeld van den toestand der brouwnering in dien tijd. Behalve de bevordering der onderlinge goede verstandhouding, met name door een gemeenschappelijken maaltijd, hadden de bijeenkomsten bijna uitsluitend ten doel het beramen

1) Zie: G. W. Kernkamp, De Droogscheerders-Synode. Historisch Leesboek, verzameld door Prof. Dr. H. Brugmans, blz. 269 vlgg.

2) In het Resolutieboek des Gemeene Brouwers binnen Delft, 7 Maart 1676-11 Augustus 1773. Gem. Arch. v. Delft.

3). Dit is blijkbaar niet het oorspronkelijke resolutieboek; maar een aan de Delftsche confrerie toegezonden copie. In het boek bevinden zich bovendien nog, op losse bladen, verslagen van vergaderingen, gehouden in 1806 en 1811 . 
van middelen om het steeds toenemend verval der bierbrouwerij tegen te gaan. rn een monografie over de Generale Brouwers hoop ik later dit alles uitvoerig uiteen te zetten; thans wil ik slechts het een en ander meedeelen over den vergeefschen strijd, welke de Hollandsche brouwers in de achttiende eeuw hebben gevoerd ter handhaving van hun aloud gistmonopolie.

Den $13^{\text {en }}$ Mei 1722 werd de gistkwestie voor 't eerst in een vergadering van de Generale Brouwers ter sprake gebracht. Dordrecht gaf het sein tot de klachten over den invoer van uitheenusche gist (droge zoowel als natte), die in den loop der achttiende eeuw telkens weer door de Hollanders zouden worden aangeheven. Daar al de leden der vergadering over den gistinvoer in hun woonplaats bleken te klagen te hebben, kwam men overeen, dat ieder zich met een klacht tot den pensionaris van zijn stad zou wenden. Dit had geen effect: in 1723 'werd de gist nog steeds „in abondantie" van buiten in de provincie ingebracht, zoodat men nu besloot om de regenten in den arm te nemen. Het volgende jaar zocht men het nog hooger op: de vergadering van $10 \mathrm{Mei}$ 1724 besloot, dat de gedeputeerden van Delft en Rotterdam in samenwerking met die van Dordrecht een request aan de Staten Generaal zouden opstellen. Het blijkt ${ }^{1}$ ), dat Brabantsche en Vlaamsche gist langs de Maas, Kleefsche langs den Rijn, en Munstersche en Friesche over Zwolle placht te worden ingevoerd.

In het request aan de Staten Generaal ${ }^{2}$ ) wordt door de brouwers hun toestand zoo zwart mogelijk afgeschilderd. Tengevolge van den vrijen onbelasten invoer van de buitenlandsche gist is, zeggen zij, het debiet daarvan zoo toegenomen, dat haast geen inlandsche gist binnen de provincie meer wordt gebezigd, zoodat zij evenals de brouwers in de andere provinciën met hun gist blijven 'zitten. Door dit nadeel, gevoegd bij de toenemende winstderving tengevolge van het algemeen verval der brouwnering, zullen zij op den duur buiten staat raken om de tot hun bedrijf noodige

1) Uit een meer uitgebreid verslag van deze vergadering, uitgebracht door een der afgevaardigden van de Delftsche confrerie, en berustend in het gemeente-archief van Delft.

2) Resolutiên der Staten Generaal van 11 November 1724 . 
panden behoorlijk te onderhouden en de daarop rustende lasten af te doen, zoodat velen hèt brouwen zullen moeten staken. Nu komt het schrikbeeld, dàt de brouwers in een groot aantal van hun requesten de overheid plegen voor te houden: vermindering van het aantal brouwerijen zal beteekenen geringer verbruik van granen en andere brouwingrediënten tot-schade van de inkomsten van het gemeene land; in dit geval noemen de brouwers, behalve de impositiën door de respectieve provinciën geheven, meer in 't bizonder de door de Unie genoten convooi- en licentgelden.

In December van hetzelfde jaar werd een tegen-request ingediend door personen, wier belang nauw bij kwesties betreffende gistdebiet betrokken was, n.l. de gildemeesteren der broodbakkersgilden te Haarlem, Delft, Leiden, Amsterdam en verdere plaatsen ${ }^{1}$ ). Deze begonnen met het optreden der brouwers als „buiten alle fondament en reden" te qualificeeren en hun voorgeven dat de invoer van vreemde gist hen ruïneeren zou als ,gansch abusievelijk." Volgens hen was het ten eenenmale onwaar, dat de brouwers met hun gist bleven zitten; integendeel, zij waren buiten staat om het geheele jaar door de bakkers en grutters met goede gist te gerieven. Die moesten meermalen - en dikwijls vruchteloos - om gist gaan naar andere plaatsen, omdat ze hun vaak in die brouwerijen in hun eigen stad, waar zij geen bier plachten te halen, werd geweigerd, of omdat de brouwersgist zoo dun was dat zij voor $\frac{3}{4}$ als onbruikbaar moest worden weggestort. Bovendien moest men haar nog zeer duur betalen; kortom in alle opzichten was men geheel aan de willekeur der brouwers overgeleverd, daar er niet in iedere stad keurmeesters bestonden, evenmin vaste prijzen of geijkte lepels. Gevolg van dat alles was, dat de bakkers de burgerij dikwijls niet naar genoegen van behoorlijk gerezen brood konden voorzien, en de grutters de arme lieden niet aan gist helpen. Werd het verzoek der brouwers ingewilligd, dan konden bakkers en grutters hün winkels wel sluiten.

De brouwers schijnen inderdaad door den invoer der vreemde gist- niet zoo benard te zijn geweest als zij het in

1) Resolutiền der Staten Generaal van 14 December 1724. 
hun request wilden doen voorkomen. Zeker wel opdat men de kracht van het laatste door hén te berde gebrachte argument beter zou kunnen beoordeelen, besloten Hunne Hoog Mogenden 't request aan de Collegiën ter Admiraliteit om advies te zenden, terwijl het door de gedeputeerden van Holland en Zeeland copielijk werd overgenomen "om in den haren breeder te worden gecommuniceerd." De advocaat, die den brouwers in deze zaak van dienst was geweest, opperde nu of het sop de kool wel waard was; het eenige malen doen copieeren van resolutie en request beide zou, naar hij verwachtte, den brouwers op groote onkosten komen te staan ${ }^{1}$ ). Deze besloten dan ook in hun vergadering van 8 Mei 1725 de zaak te laten voor wàt zij was - ware zij werkelijk van zoo vitaal belang geweest, dan zouden zij er toch allicht meer voor hebben over gehad ${ }^{2}$ ).

Deze onbesliste pennestrijd was nog slechts een voorspel van de groote polemiek.in requesten, die veertig jaar later zou worden gevoerd tusschen de Generale Brouwers aan den eenen en de bakkers en grutters uit verschillende plaatsen van Holland aan den anderen kant. Ook in de daartusschen liggende jaren is in de brouwersbijeenkomsten het gistvraagstuk ter sprake gekomen.

Op de vergadering van 30 April 1753 klaagde Rotterdam weer over den invoer van vreemde gist en stelde voor, dat de Generale Brouwers een request dienaangaande aan de Staten van Holland zouden aanbieden. Men wilde echter Hun Edel Groot Mogenden, die toen juist over het porto franco aan het beraadslagen waren, niet met requesten lastig vallen en had bovendien met het oog op de vroeger opgedane ondervindingen weinig hoop op succes. De meeste brouwersafgevaardigden besloten nu om ondershands de Admiraliteit of eenige leden der Staten van Holland van de gistmisère op de hoogte te brengen, in de hoop om langs dien .weg

1) Brief (gedateerd 15 November 1724) in het gemeente-archief van Delft.

2) Intusschen hebben zij toch blijkbaar een request gelijk aan het aan de Staten Generaal gespresenteerde bij de Staten van Holland ingediend. Zie Resolutiën der Staten van Holland van 20 December 1724. 
de gist belast te krijgen '). Zoo men dit al gedaan heeft. resultaat heeft het niet gehad.

Negen jaar later namen de Generale Brouwers de actie wederom, en nu krachtiger, ter hand. De toestand werd voor hen dan. ook steeds bedenkelijker: bij den invoer van vreemde gist was het niet gebleven; op meer dan één plaats werd nu door de bakkers kunstgist vervaardigd, te Amsterdam uit een mengsel van tarwe- of aardappelmeel en hop ${ }^{2}$ ).

Den 16en September 1762 dienden de Generale Brouwers een request in ${ }^{3}$ ) bij de Staten van Holland ${ }^{4}$ ). Het begon met de klacht over den hachelijken toeștand der brouwnering, die men aan den aanvang van elk door de Generale Brouwers gepresenteerd request aantreft. Vroeger, zoo heette het, werd er veel meer en zwaarder bier gebruikt, wat het brouwen veel voordeeliger maakte, daar de lichtere bieren - van de daartoe noodige speciën afgezien - evenveel moeite en kosten vereischten. De brouwers moesten het daarom hebben van de winst, die de afval - gist, bostel, enz. - hun opleverde; in het bijzonder stond en viel hun nering met het gistdebiet. Dat dit zoo sterk was verminderd, viel ten deele toe te schrijven aan den invoer in Holland van natte en droge gist uit de andere provinciën, Brabant en Osnabrück, ten deele aan het feit, dat de bakkers e.a. binnen de provincie van sommige speciën - waaronder eenige, die wel schadelijk voor de gezondheid konden zijn speciaal van het aftreksel van hop, zeker mengsel vervaardigden, dat in plaats van gist werd gebruikt, ofschoon het plakkaat van 9 November 1748 en nader artikel IX van

1) Resolutieboek der Gemeene Brouwers binnen Delft: notulen der comparitie van 8 Augustus 1753.

$\left.{ }^{2}\right)$ Ibidem : notulen der comparitiën van 23 Juni en 30 Augustus 1762.

3) Het doen opmaken en indienen van dit request was. in de vergadering van 24 Augustus 1762 opgedragen aan een commissie bestaande uit de afgevaardigden uit Delft, Amsterdam en 's-Gravenhage, welke ook de twee later genoemde adressen heeft doen. opstellen en aanbieden.

) Volumen der Documenten ter Vergaderinge geëxhibeert, 1762, 16 September. Algemeen Rijks-Archief. 
de ordonnantie op de binnengebrouwen bieren van 29 November 1749 aan elk, die geen publiek toegelaten brouwer was, verbood om koren, meel, mout, hop, alsem, tamarinde, suiker, siroop of honing te bezigen tot het maken van eenig bier en dus (volgens de brouwers) ook van gist, welke immers van bier of van azijnbier placht te worden getrokken. Alleen de bakkers, zoo betoogden de brouwers, trokken van het gebruik van dit mengsel een - ongeoorloofd - voordeel, niet de broodconsumenten, daar het brood werd verkocht volgens de zetting, die altijd zoodanig werd berekend dat daarin de prijs van de Hollandsche biergist aan de bakkers vergoed werd.

De brouwers vroegen een belasting van 12 stuivers per pond op de droge en 8 gulden per ton op de natte uitheemsche gist, een verbod in de eerste plaats aan allen buiten de bier- en bierazijnbrouwers om direct of indirect natte of droge gist te fabriceeren, in de tweede plaats aan de bieren bierazijnbrouwers zelf om direct of indirect andere gist te maken dan die zij respectievelijk van hun bier en bierazijn plachten te trekken. 't Laatste deel van het verzoek was in het request opgenomen op instigatie der brouwers van Rotterdam, die de vrees hadden geopperd dat men clandestien zou voortgaan met kunstgist te vervaardigen en dat de brouwers dan genoodzaakt zouden zijn om het ook te doen.

Het advies van Gecommitteerde Raden ${ }^{1}$ ) kwam ter tafel in de Statenvergadering van 5 Januari 1773, en luidde gunstig. Gecommitteerde Raden noemden het een feit, dat uitheemsche natte en droge gist meer en meer tot groot nadeel der browwers in de provincie werden ingevoerd; een zaak van ernstiger aard achtten zij evenwel de vervaardiging van kunstgist of -deesem uit verboden speciën, waarvan dan tevens in directen strijd met artikel IX der ordonnantie een zeker soort bier werd bereid, terwijl bovendien nog sommigen die kunstgisten fabriceerden van voor de gezondheid schadelijke ingrediënten. Gecommitteerde Raden achtten het dus noodig, dat zoo spoedig mogelijk een

1) Dagteekening 31 December 1762. Volurnen der Documenten enz., 1763, 5 Januari. Alg. Rijks-Archief. 
publicatie werd uitgevaardigd inhoudend, dat alle natte gist, die in Holland werd ingevoerd, zou onderhevig zijn aan een impost van 8 gulden op elke groote bierton, elk pond droge gist aan een belasting van 12 stuivers geheel overeenkomstig het verzoek der brouwers dus. Vrijgesteld van dezen impost behoorden de branders te zijn, daar die de vreemde gist in hun bedrijf noodig hadden; niemand buiten hen zou ze mogen inslaan of verkoopen behalve bepaalde personen, daartoe door de stadsmagistraten of, voor zoover het het platteland betrof, door Gecommitteerde Raden gemachtigd. Aan de bakkers moest worden verboden om eenigerlei soorten van kunstgist te maken of te gebruiken, toebereid uit mout, hop, alsem, tamarinde, suikeren, siropen, honing of andere speciën, op boete van 600 gulden, en op lijfstraf, wanneer zij eenige voor de gezondheid nadeelige ingrediënten bleken te hebben gebezigd. Uitsluitend gist uit brouwerijen en azijnmakerijen binnen de provincie of bij de publiek toegelaten gistslijters gehaald zouden de bakkers mogen gebruiken.

Overijlde besluiten te nemen ligt en lag niet in den aard van Hollandsche regeeringscolleges. De finale resolutie op request en advies werd uitgesteld totdat de leden der vergadering zooals dat heette de intentie van hun principalen zouden hebben verstaan ${ }^{1}$ ), en in dien tusschentijd regende het contra-requesten uit de kringen der oude opposanten tegen de belemmering van het vrije gistvertier: bakkers en grutters.

Het begon den 4en Februari 1763 met een request van de gezamenlijke grutters te Rotterdam en één van de hoofdlieden der grutters- en bakkersgilden binnen Delft ${ }^{2}$ ). De Rotterdamsche grutters verklaarden, dat de twaalf brouwers in hun woonplaats, hoeveel zij ook brouwen mochten, niet in staat waren om meer gist te leveren dan hoogstens de helft van de hoeveelheid, die bakkers, grutters en winkeliers noodig hadden. Aanvoer van gist van buitenaf moest daarom veeleer worden gemakkelijk gemaakt dan door het heffen

1) Resolutiën der Staten van Holland van 5 Januari 1763.

2) Resolutiën der Staten van Holland van 4 Februari 1763. Volumen der Documenten enz., 1763, 4 Februari. 
eener belasting bemoeilijkt, temeer daar. de brouwers zeker niet zouden brouwen: alleen om het gebrek aan gist en den invoer daarvan van buiten te voorkomen, daar de gist slechts een afvalproduct van het bier was - evenmin als de grutters boekweit zouden verwerken om den dop, of de bakkers tarwe laten malen om de zemelen. Ongetwijfeld zouden de brouwers zich een belasting op de vreemde gist ten irutte maken door van tijd tot tijd den prijs van hun gist-willekeurig te verhoogen; dus zou men dan niet alleen de uitheemsche, maar ook de inlandsche gist duurder moeten betalen, De belasting zou zoodoende de twaalf brouwers te Rotterdam bevoordeelen, maar groot nadeel töębrengen aan de driehonderd winkeliers ${ }^{1}$ ) en vijftien grutters daar ter stede, terwijl toch al sinds twintig jaar de hering der laatste zoo was achteruitgegaan, dat zij jaarlijks wel tweehonderd last boekweit minder dan vroeger hadden verwerkt. Zoo zwart mogelijk werden door de grutters de waarschijnlijke gevolge van de inwilliging van 't verzoek der brouwers afgeschilderd. Wanneer door een belasting op de vreemde gist hun bedrijf nog meer zou worden bezwaard, zoo betoogden zij, dan zouden zij niet langer in staat zijn om volgens de oude, binnen Rotterdam algemeene gewoonte, bij het meel eenige gist toe te geven, doordat die hun dikwijls meer dan half 'zoo duur als 't meel zou komen te staan, en een breken met dit gebruik zou bij de kleine gemeente groot gemor, zelfs oproer veroorzaken, waardoor zij grutters voor hun personen, familiën, huizen en neringen zouden komen bloot te staan aan allerlei „moedwilligheden en insultes van een tumultueuse menigte, die gewoon (was) hraar moed door plundering te koelen." Ter voorkoming van al die ijselijkheden zouden de grutters dus wel genoodzaakt zijn om de belaste gist gratis te blijven toegeven, tot hun niet gering nadeel.

De hoofdlieden der grutters- en bakkersgilden binnen Delft begonnen eveneens hun request om het vrij laten van den invoer der buitenlandsche gist met te verklaren, dat de brouwers in 't bizonder in hun woonplaats, maar ook in ' $t$ algemeen in de geheele provincie, buiten staat waren

1) Zijn hiermee'meer speciaal kruideniers bedoèld? 
om meer dan de helft van de gist te leveren, welke voor het groot aantal broodbakkerijen en' de talrijke kleine luiden, wier voornaamste voedsel in koeken van boekweitemeel bestond, benoodigd was. De brouwers hadden dus geơn recht om zich erover te beklagen, dat er ten nutte van het publiek gist van elders werd ingevoerd, en ondervonden daarvan ook geenerlei nadeel, daar desondanks de gist in de meeste tijden van 't jaar nog schaarsch was, zoozeer zelfs dat, toen ze op een keer bij de:brouwers tot geen prijs te bekomen was, er voor een pond droge gist in plaats van $4 \frac{1}{2}$ à 5 stuivers, zooals anders, 1 gulden was betaald. Van die schaarschte hadden de Delftsche brouwers uitnemend weten te profiteeren door voor een schep gist viermaal zooveel te vorderen als 't geen vroeger de gewone prijs was. Met hun verzoek hadden de brouwers dan:ook zekerlijk niets anders voor dan hun gist minstens ten bedrage van de gevraagde belasting in prijs te doen opslaan. De. invoer van buitenlandsche gist zou er in 't geheel niet door worden voorkomen, want die werd door het toenemend verval der brouwnering dagelijks meer en meer noodzakelijk - welk verval, zooals de grutters terecht in 't licht stelden, niet moest worden geweten aan den invoer van uitheemsche gist of het gebruik van eenig de gist vervangend mengsel, maar veeleer aan de steeds vermeerderende consumptie van koffie, thee, wijnen en andere dranken.

Wat het gewraakte mengsel betrof - 't welk overigens in Delft tot dan toe niet was gebezigd - dat dit nadeelig voor de gezondheid zou zijn, was volgens de requestranten niets dan „een bloot voorgeven zonder bewijs, gebaard in den boezem van eigen intrest"; er waren kundige lieden genoeg, die van de goede kwaliteiten van het mengsel waren overtugd.

Het laatste argument der bakkers. en grutters betrof de belasting zelf, die zij "extravagant en ongeproportioneerd" noemden, immers 1 ton natte gist kon veel meer dan $13 \frac{1}{3}$ pond droge uitleveren. Ten slotte uitten zij dezelfde vrees voor gemor en oproer onder de kleine gemeente als door de Rotterdamsche grutters werd aan den dag gelegd.

Drie requesten van gelijke strekking als de twee bovengenoemde kwamen in de vergadering der Staten van Holland 
van 28 Februari 1763 ter tafel ${ }^{1}$ ). Het eerste was ingediend door de overlieden van' het bakkersgilde in 's Gravenhage voor henzelf en als gequalificeerden van hun confraters van Dördrecht, Haarlem, Leiden, Amsterdam, Gouda, Rotterdam en Gorinchem, mitsgaders Maassluis, Maasland, Schipluy en andere dorpen in Delfland ${ }^{2}$ ) - de actie greep dus om zich heen. De requestranten begonnen met den brouwers er een verwijt van te maken, dat zij al veertig jaar geleden aan Hunne Hoog Mogenden „op gansch suben obreptive gegevens" om een verbod van invoer van buitenlandsche natte en droge gist hadden verzocht. Op "sub- en obreptive gegevens" was volgens hen ook het onlangs ingediende request aan de Staten van Holland gegrond, want behalve misschien in de maanden Maart en April en October en November, wanneer er om zoo te zeggen dag en nacht duurbieren gebrouwen werden, hielden de brouwers nooit eenige gist over. Toestaan van het verzoek om belasting zou beteekenen het verleenen van een gistmonopolie aan de brouwers, die de bakkers nu al tweemaal zooveel deden betalen als voor veertig à vijftig jaar, en dan stellig hun gist nog duurder zouden gaan verkoopen, waardoor veel bakkers, die nu met slaafschen arbeid in 't zweet huns aanschijns nauwelijks droog brood voor zich en hun gezin konden verdienen, tot den bedelstaf zouden worden gebracht, tenzij naar evenredigheid van den hoogen gistprijs de zetting van het brood en meel werd verhoogd. De gevolgen, die dit laatste, zou kunnen hebben, werden weer in de somberste kleuren afgeschilderd: brood en meel, nu reeds zeer duur, zouden dan door de armen in 't geheel niet meer kunnen worden betaald, zoodat die zich uitsluitend met aardappelen - een onbelast consumptiemiddel - zouden moeten voeden, waardoor weer niet alleen de bakkers zouden worden 'benadeeld, maar ook het gemeene land door de verminderde opbrengst van den impost op het gemaal, om niet te spreken van de oproerigheid, die van dat alles het gevolg zou kunnen zijn.

1) Resolutiën der Staten van Holland.

2) Volumen der Documenten enz., 1763, 23 Februari. 
Wat nu den zetdeesem betrof, waarvan de bakkers hadden gebruik gemaakt wanneer noch inlandsche noch uitheemsche gist te krijgen was, dat deze de gezondheid niet schaadde leerde niet alleen de ondervinding, maar 't werd ook. voldoende gewaarborgd door de ingrediënten: meelbloem en afkooksel van hop. De plakkaten verboden alleen het brouwen van bier uit bepaalde speciën; door gist te vervaardigen overtrad men ze dus niet. Intusschen gaven de bakkers aan 't gebruik der kunstgist allerminst de voorkeur," daar de bereiding veel moeite en tijd kostte; veel liever zouden zij door de brouwers tegen een behoorlijk gezetten prijs van de noodige gist worden voorzien.

't Geheele verzoek der brouwers werd ten slotte door de bakkers als hoogst onredelijk gebrandmerkt. De brouwers, die uit de winsten, welke hun bedrijf, ja zelfs reeds de afval van het product daarvan, hun opbracht, als groote heeren leefden en "brillante equipagiën" hielden, trachtten, zoo klaagden zij, een last te doen leggen op een nederig beroep, waarvan de geringe voordeelen met zuren en slaafschen arbeid moesten worden gewonnen, terwijl het in de publieke inkomsten het meeste en 't getrouwst bijdroeg, daar de bakkers lands- en stadslasten op het gemaal evenals het maalloon reeds daags voordat de granen naar den molen gingen moesten betalen - vaak voor personen, van wie zij later nooit een penning ontvingen, terwijl de brouwers den impost op het bier nooit voorschoten. Laatstgenoemden genoten bovendien voor hun gezin, hun personeel in de brouwerijen en allen die daarin kwamen om eenigen dienst te verrichten vrijdom van bierimpost, terwijl de bakkers geen stuk brood konden eten of aan een arm mensch schenken zonder dat daarvan door hen de impost op het gemaal was betaald; veel bakkers konden dan ook nauwelijks een sober kostje winnen en waren op hun ouden dag niet in staat om hun eigen brood te eten. Met de bede aan Hun Edel Groot Mogenden om door 't. afwijzen van het verzoek der brouwers de bakkers der provincie voor hun totalen ondergang te bewaren eindigde het request.

Van de broodbakkers en grutters te Brielle kwam het betoog ${ }^{1}$ ) vrijwel op hetzelfde neer als dat van de verschil-

1) Volumen der Documenten enz., 1763, 23 Februari. 
lende andere requestranten. 't Was er zoover vandaan dat de brouwers met hun 'gist zouden blijven zitten, dat het eerder als seen gunstii:moest worden beschouwd wanneer men op tijd werd geriefd, waartoe dan vaak een brouwersknecht of ander ondergeschikte moest worden in den arm genomen. En uit vrees van in 't geheel geen gist meer te zullen krijgen durfde men zich nog niet eens te beklagen wanneer de gist met dunnebier of water was aangelengd, wat de brouwers deden juist om in het tekort aan gist te voorzien. Nam de buitenlandsche gist zoozeer in prijs toe als tengevolge van de inwilliging van 't verzoek der brouwers het geval zou zijn, dan zouden de supplianten zich die niet 'meer kunnen verschaffen en geheel op de dikwijls slechte ein" vermengde gist der brouwers zijn aangewezen, waarvoor deze dan zooveel zouden kunnen vragen als zij goedvonden - want kunstgist 'was' te iBrielle onbekend. Nam men daarbij het voordurend tekort aan brouwersgist in aanmerking, dan was het duidelijk, dat de bakkers en grutters menigmaal hun nering zouden moeten stop zetten.

Boekhouder en dekenen van de grutters en van het broodbakkersgilde te Dordrecht hielden staande '), dat de negen brouwerijen daar ter stede zelfs in gewone tijden op verre na niet de helft van de benoodigde gist konden leveren, om van de zomermaanden - wanneer er minder gebrouwen werd - niet te spreken. Ondanks den vrijen toevoer van buiten was de gist dikwijls zoo schaarsch, dat de brouwers het den gegadigden als een gunst toerekenden wanneer zij ze hun tegen hoogen prijs uit de brouwerijen leverden. Blijkbaar was 't den brouwers nergens anders om te doen dan den gistprijs nog meer op te drijven; nu was die al tweemaal zoo hoog als velen zich nog van vroeger tijd herinnerden, waardoor sommige brouwers in Dordrecht met den gistverkoop alleen meer dan 1200 gulden verdienden. Dan werd de gewone rij van te vreezen gevolgen van het duurder worden der gist opgenoemd: of hoogere zetting van brood en boekweitemeel en daardoor ongenoegen der kleine gemeente met "facheuse" gevolgen, òf de nekslag voor de neringen der grutters en bakkers, zoodat in Dor-

1) Volumen der Documenten enz., 1763, 23 Februari. 
recht alleen ongeveer honderd huishouders zouden worden opgeofferd aan negen brouwers, , en dat ter zake van een specie voor de brouwers bijkomstiga. maar een wezenlijk en eerste ingrediënt voor de bakkers en grutters, die zẹker niet minder dan de branders er aanspraak op konden maken om ten opzichte daarvan niet te worden bezwaard, te meer daar de bakkers - te Dordrecht tachtig in getal tot het bakken van wit of klein goed de minder bittere vreemde gist volstrekt noodig hadden, terwijl bovendien het product van hun bedrijf heel wat nuttiger en onontbeerlijker was dan sterke drank.

De overlieden der grutttersgilden binnen Dordrecht, Leiden, Amsterdam, Gouda, Schiedam, Schoonhoven, Alkmaar ẹn Den Haag, wier request 1 Maart 1763 in de vergadering der Staten van Holland werd ter tafel gebracht ${ }^{1}$ ), , beweerden, dat er in den afgeloopen winter binnen Amsterdam en elders wel een derde meer meel zou zijn verkocht, indien er geen gebrek aan gist was geweest; meel kon niet gedebiteerd worden als er geen gist was. Onder tekort aan gist leed dus vooral de nering der grutters, bakkers en andere meelverkoopers, wier aantal dat der brouwers vẹr overtrof. Amsterdam alleen telde, de meer dan zeshonderd bakkers daaronder niet begrepen, over de duizend grutters en meelverkoopers tegen veertien of vijftien brouwers. Minder debiet van meel door gebrek aan gist - hetwelk natuurlijk door een belasting in de hand zou. worden gewerkt - bracht met zich geringere opbrengst van den impost op het gemaal, terwijl de belasting bovendien onvermijdelijk verhooging van de zetting op den meelprijs en zoo alweer minder meelverbruik tengevolge zou hebben.

In de vergadering der Staten van Holland van 3 Maarit werd een request gelezen van grutters en bakkers binnen Schiedam en Vlaardingen ${ }^{2}$ ), die hadden berekend, dat door 't heffen der belasting elk brood en iedere maat boekweitemeel met vier penningen zou worden bezwaard - een groote

1) Resolutiën der Staten van Holland. Volumen der Documenten enz., 1763, 1 Maart.

$\left.{ }^{2}\right)$ Resolutiën der Staten van Holland. Volumen der Documenten enz., 1763, 3 Maart. 
hardheid tegenover de supplianten, die aan een bepaalde zetting gebonden waren; en de kleine luiden, die zich in hoofdzaak met brood en boekweitemeel plachien te voeden, en vroeger al eens wegens duurte dierzelfde eetwaren in oproer waren gekomen. Verder vreesden $\mathrm{zij}$, dat tengevolge der belasting de haring- en vischvangst binnen Vlaardingen gevoelige schade zouden ondervinden, doordien de bakkers daar, als zij geen of niet genoeg buitenlandsche gist tot hun beschikking hadden, niet in staat zouden zijn om een invallende vloot schepen zoo spoedig te gerieven dat die weer op tijd zou kunnen afvaren.

Het werd een zeer uitvoerig stuk, 't request waarin de brouwers, nogmaals op inwilliging van hun verzoek aandringend, al de betoogen en argumenten van hun tegenstanders weerlegden ${ }^{1}$ ). In scherpte van toon doet het voor de bovenvermelde requesten niet onder: den bakkers wordt naar het hoofd geworpen dat zij alles op haren en snaren zetten om hun "onmatige en ongepermitteerde" winst te blijven genieten ${ }^{2}$ ); als "verkeerde imputatiën en invectives" wordt hetgeen in de contra-requesten is te berde gebracht gequalificeerd, een geaffecteerde "terreur panique" noèmen de brouwers de algemeen aan den dag gelegde vrees voor gemor en oproer onder de smalle gemeente.

Met nadruk verklaarden de brouwers, dat zij wel degelijk gaarne wilden brouwen oin den afval alleen, met name de gist, wanneer zij die maar konden debiteeren; de vergelijking met bakkers en grutters, wier bedrijf slechts afval van zeer geringe waarde opleverde, ging niet op. Dat geen brouwerij meer kon bestaan van de winst door het bier alleen opgeleverd was door de opposanten nergens tegengesproken, evenmin dat natte en droge gist uit andere provinciën, Brabant en Osnabrück in Holland in groote hoeveelheden werd ingevoerd en tegen aanmerkelijk lageren prijs dan de Hollandsche gedebiteerd - waaruit volgens de brouwers "eenvoudig en zeer natuurlijk" volgde, dat zíj van hun gist geen vertier hadden. Zoo onweersprekelijk als zij het willen

i) Resolutiën der Staten van Holland van 6 April 1763. Volumen der Documenten enz., 1763, 6 April.

$\left.{ }^{2}\right)$ Nl. doordat bij de zetting van het brood de - duurdere Hollandsche gist werd vergoed; zie boven, blz. 392 . 
doen voorkomen is dat echter niet; de vraag is maar of er inderdaad zooveel uitheemsche gist werd ingevoerd, dat men de brouwersgist geheel of voor een groot deel missen kon. De brouwers achtten het hoogst onbillijk, dat zij, die zoowel uithoofde? van hun nering, als van hun. zware vaste panden jaarlijks zooveel aan het gemeene land betaalden, ten opzichte van hun gist in de provincie in ongunstiger conditie verkeerden dan vreemdelingen, die veel geld uit de provincie sleepten zonder dat de-gemeene kas er iets van profiteerde - aan welken misstand door het heffen der verzochte belasting een eind kọ worden gemaakt. Dan zou 1 pond droge buitengist in plaats van $4 \frac{1}{2}$ stuiver zooals nu $16 \frac{1}{2}$ stuiver komen te kosten; in de brouwerijen moest men voor $\frac{1}{2}$ ketel Delftsche maat natte gist, welker werking met die van 1 pond droge kon worden gelijkgesteld, 22 stuivers geven; de vreemde gist bleef dus altijd nog goedkooper, maar voor de inlandsche werd de concurrentie toch minder bezwaarlijk. Tegen het verwijt dat zij een onevenredige belasting vroegen verdedigden de brouwers zich met het betoog, dat de eene ton natte gist meer gistsubstantie inhield dan de andere, zoodat men er geen peil op kon trekken hoeveel pond droge gist 1 ton natte kon opleveren; bovendien was de natte gist duurder en meer aan bederf onderhevig, en werd meestal ingevoerd uit de naburige provinciën en 't ressort der Generaliteit, terwijl de droge uit andere meer verre en vreemde landen. kwam; daarom hadden de brouwers gemeend, dat de natte gist minder zwaar dan de droge moest worden belast.

Met kracht kwamen de brouwers op tegen het hoofdargument der bakkers en grutters, dat zij niet in staat zouden zijn de noodige gist te leveren; integendeel, terwijl zij van October tot Mei, beide maanden inbegrepen, bij den verkoop der gist meer plachten te geven dan zij volgens de gezette maat behoefden te doen, moesten zij in zes of zeven maanden de gist weggooien; in Amsterdam alleen was van 17 tot 27 Februari 1763 een hoeveelheid gist ter waarde van 1500 gulden in 't water geworpen. Indien er al in 't zomerseizoen op den een of anderen dag in een brouwerij geen gist te krijgen was, dan kon men die doorgaans wel bij een anderen brouwer bekomen, die op andere 
dagen gebrouwen had. Trouwens, aangenomen dat de brouwerijen soms niet al de benoodigde gist leveren konden, de mogelijkheid om vreemde gist te bekomen werd immers niet afgesneden; en nadeel zouden bakkers en grutters niet ondervinden, daar de prijs van de buitengist ook na het invoeren der belastingen, dien van de Hollandsche, waarmee in de zetting van brood en meel rekening was gehouden, niet zou te boven gaan. Van verhooging der zetting behoefde dus geen sprake te zijn, en ongegrond was daarom de vrees, dat de smalle gemeente tengevolge der belasting zeer zou worden gedrukt, met name doordat de grutters dan geen gist meer zouden kunnen toegeven, welke noodig was tot de bereiding van boekweitekoeken, het hoofdvoedsel der kleine luiden. Dat de grutters die gist toegaven was trouwens in 't geheel niet waar; die werd hun doorgaans in de zetting van het meel bij elk pond vergoed of boven de zetting apart betaald. En bovendien, er waren nog genoeg andere spijzen, waarmee het gemeen zich voeden kon.

In 't bizonder "geaffecteerd" noemden de brouwers de vrees, dat een invallende vloot haringschepen door gebrek aan gist niet spoedig genoeg aan brood zou kunnen worden geholpen om weer terstond zee te kiezen. Behalve dat er voor geen gebrek aan gist, Hollandsche of uitheemsche, te vreezen viel, kwamen de schepen niet vlootsgewijze thuis, maar elk als het den schipper goeddocht, en vertrokken voor hun tweede reis wanneer boekhouder of reeder het den geschikten tijd achtten; daarbij kwam het voor de haringschepen, als ze al eens in grooten getale binnenvielen, op hetzelfde neer of zij moesten wachten op gist of brood of op de scheepsbieren, welke zaken alle tegelijk te krijgen waren in die steden, waar men gewoon was ze te halen.

Van de grutnering te Rotterdam viel volgens de brouwers de achteruitgang volstrekt niet aan gebrek aan gist te wijten - er was immers totnogtoe in 't geheel geen belasting geheven - maar deels daaraan, dat er veel meer aardappelen dan vroeger gegeten werden - waaruit ook volgde, dat er in Rotterdam nu minder gist noodig was - deels aan ' $t$ feit, dat het den grutters thans was verboden om zooals tevoren onder Delft, Gouda en elders met meel te gaan venten; de grutters klaagden dus feitelijk over het missen 
van een gewin, dat zij op het grondgebied hunner naburen ten nadeele hunner confraters aldaär min of meer tersluiks plachten te komen zoeken.

Dat de brouwers den gistprijs van tijd tot tijd hadden verhoogd, wat volgens deze zelf geheel bezijden de waarheid; integendeel, in plaats van sinds veertig à vijftig jaar in prijs te zijn verdubbeld kostte de gist nu $\frac{1}{3}$ minder. De bakkers, grutters en winkeliers in Delft en Delfland werden meer in 't bizonder uitgedaagd om waar te maken, dat iemand van hen zelfs in den tijd van de grootste schaarschte in de bouwerij, waar hij gewoon was gist te halen, meer betaald had dan den gebruikelijken prijs. Of een enkele buitenman in 't vinnigst van den afgeloopen winter zooals ook in 1740 de gist duurder dan gewoonljijk had moeten betalen, ging den vasten klanten niets aan, zoolang die geen nadeel ondervonden.

De vrees, dat de brouwers den prijs der Hollandsche gist naar welgevallen zoo zouden verhoogen, dat die vaak de helft der waarde van het meel zou te boven gaan, kon gerust ijdel worden genoemd; tot het bakken van brood van vifftien zakken tarwe of meel was nog geen vat gist noodig: rekende men nu den prijs per zak op 7 gulden, dan was het duidelijk, dat, al kwam het vat gist op 10 of meer gulden te staan, de prijs der gist in vergelijking van de helft van dien van 't bakmateriaal toch niets beduiden zou. Bovendien had sinds lang elke stad een door 't gebruik geijkte vaste maat en prijs, welke niet zoomaär door de brouwers kan worden veranderd.

Wat het verdunnen der gist betrof, waar de bakkers zoo over klaagden, alleen reeds uit welbegrepen eigenbelang zouden de brouwers dit nalaten - maar in het eene seizoen liep de gist veel dikker dan in het andere van het bier af; ook de buitengist werd 's zomers dunner dan anders ingevoerd en verkocht.

Ten eenenmale onwaar was het, dat het gemeene land aan impost meer voordeel trok van het bedrijf der bakkers dan van de brouwnering; de brouwers betaalden niet alleen getrouw den impost van de vele speciën noodig tot de bierbereiding, maar ook voor hetgeen in hun huishouding en brouwerijen werd geconsumeerd per brouwt 12 stuivers. 
Daarbij kwam nog. dat zij in de meeste steden den bieraccijns plachten voor th schieten, en dan bij bankroeten op de failliete boedels geen 't minste recht van preferentie hadden, ten opzichte van den voorgeschoten accijns zoo min als van het geleverde bier, terwijl althans in 's Gravenhage de bakkers voor $\frac{1}{3}$ hunner pretenties drie jaar lang waren geprefereerd. De "malice", waarmee de hier besproken "invectieve" der bakkers was ,geavanceerd," kwam allerminst te pas tegenover de brouwers, onder wie er waren geweest en nog waren, die vanwege hun stad waren vereerd met de commissie ter dagvaart van Hun Edel Groot Mogenden, en wien dus het houden van een fraaie equipage ruim zoo wel paste als den bakkers, die, wanneer zij als groote heeren zouden willen gaan leven, bij de brouwers slechts spot en lachtlust zouden opwekken.

De brouwers zetten verder uiteen, dat tusschen grutters. en bakkers aan den eenen en branders aan den anderen kant ten opzichte van vrijstelling van de belasting geen parlalel kon worden getrokken. De branders hadden vooral droge gist noodig, die van buiten komen moest, en gebruikten alleen bij gebreke daarvan natte, terwijl grutters en bakkers voornamelijk natte gist bezigden. Bovendien was het aantal bakkers in de provincie aanzienlijk, dat der branders veel geringer; vrijstelling der laatste zou de gemeene kas dus niet zeer benadeelen. Bleven grutters en bakkers van de verzochte belasting bevrijd, dan zouden de brouwers daarvan geenerlei voordeel hebben.

Het slot van 't request was gewijd aan de kwestie van de kunstgist of zetdeesem. Schaamteloos noemden de brouwers de verklaring der grutters en bakkers binnen Delft, dat totnogtoe daar ter stede geen kunstgist was gebruikt: in de Hollandsche Historische Courant ') van 4 November 1762 noodigde Egbert Thoen, bakker te Delft, al zijn confraters aldaar uit om hun eigen gist, welke men "zeer profijtelijk" gebruiken en een maand goedhouden kon, te komen leeren maken; brood met voornoemde gist gebakken zoù bij hem dagelijks te zien zijn. Alleen aan de „prijselijke voorzorg" van den magistraat te Delft was het te

1) Te Delft gedrukt. 
danken, dat den bakkers het verder gebruik van 't mengsel in de stad was belet ${ }^{1}$ ). Wel degelijk volgde uit artikel IX der ordonnantie op de bieren, dat van de daar genoemde speciën - o.a. hop, welke de bakkers zelf erkenden te gebruiken - geen gist mocht worden gemaakt; immers die kon er niet zijn voordat er bier was bereid. De brouwers hadden in 't geheel niet positief beweerd, dat de gebezigde ingrediënten schadelijk waren voor de gezondheid; alleen de vrees daarvoor hadden zij in hun request uitgesproken. Overigens beriepen zij zich op Gecommitteerde Raden ${ }^{2}$ ).

Resumeerend verklaarden de bouwers nog eens, dat zij in staat waren om genoeg gist te leveren, maar ze niet debiteeren konden, terwijl, al was er gebrek aan gist, het toch zeker geen onverschillige zaak was of dit tekort al of niet werd aangevuld door een productschadelijk voor'de gezondheid.

In een request van den 23 en September $1763^{3}$ ) repliceerden de overlieden van het bakkersgilde in 's Gravenhage voor henzelf en als gequalificeerden van hun confraters in andere plaatsen ${ }^{4}$ ). De terminologie wordt er in den loop van den strijd niet hoffelijker op: het heet nu, dat de brouwers "uit abusieve assumtiën, fallacieuse illatiën en getorqueerde raisonnementen hadden opgemaakt eenige specieuse argumenten, die van nabij beschouwd wel geen steek kunnen houden, maar in den eersten opslag een dekkleed van uiterlijken schijn hebben." Tegenover de - niet met bewijzen gestaafde - verzekering der brouwers, dat $z \mathrm{ij}$ in staat waren om de noodige gist te leveren, stelden

1) Burgemeesteren van Delft hadden Thoen en den courantier voor zich doen verschijnen, den eersten verboden om voortaan zulk een aanbieding in een courant te plaatsen of iemand te leeren gist te maken, en don laatsten om een dergelijke advertentie op te nemen. Den $11^{\text {en }}$ November 1762 lieten zij een stadsbode met den knecht van het bakkersild bij al de bakkers rondgaan en deden hen schriftelijk weten, dat zij voortaan geen andere gist mochten gebruiker dan die uit de bierbrouwerijen binnen de stad.

Resolutieboek van de Gemeene Brouwers binnen Delft: comparitiën van 10 November 1762 en 19 Januari 1763.

2) Zie boven, blz. 392 .

3) Resolutiën der Staten van Holland van 23 September 1763. Volumen der Documenten enz., 1763, 23 September.

4) Zie boven, blz. 396 . 
de bakkers de positieve verklaring, dat men sinds menschenheugenis dagelijks het tegendeel ervaren had. Ja vroeger, toen de brouwerijen rzoo enorm veel talrijker waren en de bevolking daarbij dunner, kon er voor weinig geld genoeg brouwersgist aan bakkers, grutters enz. geleverd worden, en was men niet zooals thans genoodzaakt om tot het gebruik van buitenlandsche gist zijn toevlucht te nemen. Proeven, opzettelijk in 1746 en '54 te Amsterdam genomen, hadden uitgewezen, dat de brouwers de benoodigde gist niet leveren konden, en in Amsterdam waren nog de meeste brouwerijen - maar ook de meeste ingezetenen, zoodat deze laatste opmerking van de bakkers geen steek houdt.

Trouwens met hun verzoek om belasting bewezen volgens de bakkers de brouwers zelf, dat zij in de behoefte aan gist niet konden voorzien, want anders zouden zij wel om een uitvoerverbod hebben gevraagd. Was er in Amsterdam inderdaad gist weggeworpen, dan zou dat weggietsel wel uit slecht bier vermengd met eenige bedorven gist hebben bestaan, dat men opzettelijk had in 't water gegooid om den indruk te wekken dat er overvloed van gist was geweest.

Ofschoon de bakkers zelf, zooals men ziet, erkennen dat het aantal brouwerijen aanmerkelijk is afgenomen, hetgeen toch zeker niet op bloei der nering wijst, willen zij toch de klacht der brouwers over vermindering van debiet weerleggen met te wijzen op hun "pompeuze levenswijze" ook een argument dat weinig steek houdt, want het kunnen wel niet de inkomsten uit de brouwerijen zijn geweest, maar het particulier vermogen der brouwers, in gunstiger tijden door de voorzaten vergaard, 't welk hun veroorloofde op grooten voet te leven. Overigens hadden volgens de bakkers de brouwers het zelf in hun macht om hun debiet te doen toenemen, nl. door betere bieren te brouwen; die waren in 't bizonder in Den Haag zeer dun en slecht, daar de gist zoo sterk van de bieren placht te worden afgedreven dat ze daardoor hun beste kracht verloren.

Een „eigendunkelijke calculatie" noemden de requestranten de berekening der brouwers, dat de bakkers na het invoeren der belasting voor 1 pond droge gist nog $5 \frac{1}{2}$ stuiver minder dan voor $\frac{1}{2}$ ketel Hollandsche gist zouden betalen. Om te beginnen paste het den brouwers al niet te spreken van 
de zetting van het brood en 't geen daarin den bakkers vergoed werd, omdat die een geheim was tusschen de respectieve magistraten te eener en'de beëedigde broodzetters te anderer zijde. Maar bovendien deugde de berekening in het geheel niet. De droge buitengist kostte op zijn goedkoopst niet minder dan 6 stuivers het pond, meestal $8,10,12,16$ tot 20 stuivers toe, zooals in den laatsten winter. Rekende men daarbij de transportkosten, dan kwam 1 pond op evenveel ja meer dan $\frac{1}{2}$ ketel Hollandsche gist; wanneer het nog met 12 stuivers werd belast op meer dan 30 stuivers. Als men nu in aanmerking nam, dat de brouwers de Hollandsche gist met $\frac{3}{4}$, soms $\frac{7}{8}$ dun bier plachten te vermengen, dan bleek, dat de bakkers inderdaad per halven ketel 4 gulden 8 stuivers of 5 gulden 10 stuivers ') in plaats van 1 gulden 2 stuivers betaalden. Aangenomen dat de bakkers met 1 pond droge buitengist evenveel konden doen als met $\frac{1}{2}$ ketel Hollandsche, en dat pond ${ }^{2}$ ) met den inhoud van $\frac{1}{2}$ ketel vermengden, dan gaven ze voor een hoeveelheid van 2 halve ketels 5 gulden 10 stuivers of 6 gulden 12 stuivers, zoodat de halve ketel hun dan door elkaar 2 gulden 15 stuivers of 3 gulden 6 stuivers kostte in plaats van 1 gulden 2 stuivers. Onvermengd met Hollandsche gist konden de bakkers de uitheemsche niet gebruiken, daarvoor was die te bitter. ${ }^{3}$ )

Wat nu den zoo 't heette ongezonden zetdeesem betrof, onder de Hollandsche gist was er dikwijls veel gezwavelde, afkomstig van de sterk gezwavelde bieren, welke naar de West verzonden werden, die, terwijl ze voor goede gist moest worden betaald, alles deed bederven wat ermee gebakken werd, en toch zeker ook als nadeelig voor de gezondheid moest worden beschouwd.

In verband met de vrees voor oproer deelden ten slotte de bakkers nog mee, dat zij al meer dan eens "verregaande

') Dit laatste cijfer klopt niet; het zou juist zijn, wanneer de bakkers hadden beweerd, dat de brouwers de gist met $\frac{5}{5}$ niet $\frac{7}{8}-$ dun bier vermengden.

2) De prijs dus gesteld op 22 stuivers.

$\left.{ }^{3}\right)$ Deze mededeeling is in strijd met hetgeen boekhouder en dekenen van de grutters en het broodbakkersgilde te Dordrecht in hun request zeggen (zie boven blz. 399). Misschien lag het er aan uit welke streek men de vreemde gist placht te betrekken. 
remarques" door de kleine luiden hadden hooren maken over de periode in 't request der brouwers, alsof het er weinig toe zou doên als de kleine gemeente geen brood meer tot haar dagelijksch voedsel gebruiken kon, daar er genoeg andere spijs was.

Het laatste woord in deze gistpolemiek behielden de Generale Brouwers, die 1 December 1763 nogmaals een request bij de Staten van Holland indienden '). Het begon weer met een argumentatie over het hoofdpunt van geschil: of de brouwers al dan niet genoeg gist leveren konden. De brouwers toonden aan, dat de bakkers te dien opzichte zichzelf tegenspraken: als de gist inderdaad zoo gretig placht te worden weggehaald als de bakkers het wilden doen voorkomen, hoe kon er dan in den afgeloopen winter bedorven gist zijn overgeschoten?

Toch schijnen de broûwers met betrekking tot deze kwestie zich niet geheel en al op hun gemak te hebben gevoeld, want zij verklaarden, dat het er ook weinig toe deed of er veel of weinig Hollandsche gist te krijgen was, daar zij geen verbod van invoer, maar slechts een belasting verzochten; over aantal en vermindering der brouwerijen behoefde men dus ook niet in beschouwingen te treden. De mededeelingen der bakkers omtrent de in 1746 en '54 genomen proeven waren overigens onjuist; de leden van 't Gerecht van Amsterdam, speciaal die, welke in de betrokken commissie hadden gezeten - en die "tot merkelijk geluk der supplanten" nog niet alle waren overleden - zouden kunnen bevestigen, dat, toen in 1746 de Amsterdamsche bierbrouwers verzocht hadden om een verbod van gistinvoer in de stad, voorgesteld was een proef te nemen als bedoeld, waartoe de brouwers toen zekere voorzorgen hadden aan de hand gedaan, zonder welke het onderzoek geen betrouwbare resultaten zou kunnen geven. Daar de overlieden der bakkers echter van die voorzorgen niet hadden willen weten, was de proef nooit genomen, althans niet onder de auspiciën der overheid, want wel hadden de Amsterdamsche brouwers in hetzelfde jaar 1746 op eigen gelegenheid door een proefneming aangetoond, dat - nog ongerekend de bier-

1) Resolutiën der Staten van Holland van 1 December 1763. Volumen der Documenten enz., 1763, 1 December. 
azijnmakersgist - de Amsterdamsche brouwerijen zelfs meer gist konden leveren dan bakkers, en grutters noodig hadden tot het meel, dat zij dagelijks veraccijnsden '). En nú zou zulk een proefneming voor de brouwers nog gunstiger uitvallen, 10 omdat er in Amsterdam zooveel Fransch brood, 't welk men zonder gist bereidde, door rijk en arm gegeten werd dat $\frac{1}{5}$ der bakkers daàr Fransch-brood-bakkers waren, 20 omdat door allerlei slag van menschen ongelooflijk veel roggebrood.werd geconsumeerd, 30 omdat thans op alle tafels aardappelen werden opgedischt.

Noemen de Haagsche bakkers de berekening der brouwers eigendunkelijk, de brouwers van hun kant spreken van de "woeste" en "in vago geformeerde" calculatie der bakkers, waarop niet de minste staat kan worden gemaakt. De brouwers hadden hun berekening gebaseerd op hetgeen de bakkers en grutters in hun. request van 4 Februari 1763 zelf met zooveel woorden hadden te kennen gegeven, n.l. dat men buiten tijden van schaarschte voor 1 pond droge buitengist $4 \frac{1}{2}$ à 5 stuivers betaalde - nota bene met bereidverklaring om het desverlangd met bewijzen te staven en door geen der betrokkenen behalve de Haagsche bakkers was tegen die uitlating omtrent den prijs opgekomen. Verder hadden de brouwers alleen gesproken van de ongeoorloofde winst door het gebruik der enkele droge buitengist behaald, onvermengd met andere - welke tegenwerping wel eenigszins als een uitvlucht aandoet. Transportkosten - die trouwens werden opgegeven noch begroot mochten niet in rekening worden gebracht, daar die immers in den gistprijs waren inbegrepen en volstrekt niet afzonderlijk werden voldaan. De conclusie, dat 1 pond droge buitengist evenveel, ja meer zou kosten dan $\frac{1}{2}$ ketel Hollandsche, en met het bedrag der belasting erbij op meer dan 30 stuivers zou komen te staan, ging dus aan alle zijden mank, daar de premissen niet alleen maar onzeker, neen abusief waren.

Futiel noemden de brouwers de klacht, dat zij hun gist

1) Van de proefneming in 1754 wordt hier dus niet gerept. Was het in het belang der brouwers om over die laatste proef het stilzwijgen te bewaren? 
met $\frac{3}{4}$ of zelfs met $\frac{7}{8}$ dun bier zouden vermengen, zoodat de bakkers die vier of acht maal te duur betaalden - want, ofschoon inderdaad de' gist met eenig ander vocht, 't zij water of bier, werd en moest worden aangelengd, omdat ze anders, tenminste in den zomer, binnen tweemaal vieren-twintig uur, bij groote hitte zelfs binnen vier-en-twintig uur, goor zou zijn - de bakkers betaalden niet alles wat in den ketel was, maar alleen de wezenlijke gist zelf, en de kracht daarvan stond gelijk met, ja overtrof zelfs die van 1 pond droge buitengist.

Dat de bieren, waarvan de prijs nooit opgeslagen werd, in de laatste jaren eenigșins in kwaliteit waren achteruitgegaan, verklaarden de brouwers desnoods zeer goed te kunnen rechtvaardigen ${ }^{1}$ ). Voor de insinuatie der bakkers daaromtrent gaven zij een andere terug: hoe kwam het, vroegen zij, dat het brood, hetwelk wel in prijs opsloeg, zoo slecht werd gebakken dat de gemeente er niet weinig over klaagde, in 't bizonder over het met kunstgist toebereide?

Wat ten slotte de kwestie van de gezwavelde gist betrof, de brouwers begrepen niet hoe de bakkers ooit, laat staan dikwijls, eenige ondervinding van dien aard konden hebben opgedaan. Slechts in zeer weinig steden toch brouwde men bieren voor Oost- en West-Indië, en gezwaveld werd alleen een weinig de fust waarin ze werden gevaat om te gisten en daarna te worden verstuurd; de gist kon niet zijn aangedaan, zoowel omdat de zwavel gedurende den tijd dat die bieren lagen te gisten 't meeste van zijn geest verloor als omdat de gist van die bieren - die daarvan trouwens slechts in zeer geringe hoeveelheid afliep - evengoed met water werd aangelengd en gezuiverd als de gist van ander bier. En al zou er van die zwavel eens eenige geest onder de gist komen, dan was het nog onaannemelijk dat die gist jets zou doen bederven of nadeelig voor de gezondheid zijn. Was daar echter eenige kans op, dan waren de brouwers gaarne bereid om die gist te laten wegloopen.

1) De ingrediënten werden nl. wel duurder, zooals bij andere gelegenheden door de brouwers herhaaldelijk wordt in 't licht gesteld. 
Aan Gecommitteerden tot de Zaken van de Finantiën werd door de Staten van Holland opgedragen om met Gecommitteerde Raden omtrent al deze stukken de vergadering van advies te dienen. Dit advies, waarvan den 23en April 1765 door den raadpensionaris rapport werd uitgebracht ${ }^{1}$ ), schijnt niet te zijn overgeleverd, wel een praeadvies van Gecommitteerde Raden, den 16 en Maart 1764 ter tafel gebracht in .een besogne ${ }^{2}$ ). Gecommitteerde Raden toonden zich ondubbelzinnig op de hand der brouwers. Met betrekking tot het verzoek om een verbod van kunstgist ver: klaarden zij, dat zij geen tegenargumenten van gewicht in de requesten der bakkers hadden kunnen ontdekken, zoodat men te dien opzichte het verlangen der brouwers zonder eenig bedenken kon inwilligen, te meer - en nu komt dé typisch-conservatief-kortzichtige redeneering - daar het gebruik dier kunstgist een volstrekte nieuwigheid was, waaraan men tevoren zoolang er brood in Holland gebakken werd nooit had gedacht, waaromtrent dus niet te bepalen viel welk nadeel daaruit voor het land en het algemeen zou kunnen voortkomen!

Wat het verzoek om belasting op de buitengist betrof, Gecommitteerde Raden beriepen zich op de als regel gevolgde protectionistische politiek van Hun Edel Groot Mogenden: altijd, wanneer men buitenlandsche goederen in de provincie aanzienlijk goedkooper dan de inheemsche had verkocht, waren ze in die mate belast dat dit niet meer kon plaats hebben. Zoo was tot steun der zoutketen een verhoogde impost gelegd op het van buiten inkomend zout, eveneens op de inkomende koornbrandewijnen tot steun der branderijen en op den buiten de provincie gebakken steen ten behoeve der steenbakkerijen, terwijl de grutterijen werden beschermd door een hoogeren impost op de gerulde boekweit en een zeer zware belasting op den invoer van meel. De tot steun der bakkerijen geheven belasting op het van buiten inkomend brood ging den binnenlandschen impost op het tarwebrood meer'dan driemaal, dien

1) Resolutiën der Staten van Holland van 23 April 1765.

$\left.{ }^{2}\right)$ Documenten, die gedrukt en niet geïnsereert zijn in de gedrukte Resoluties van Hun Edel Groot Mogenden, 1764 en '65. Alg. R. Arch. 
op het roggebrood wel zevenmaal te boven. Billijk was het dus, dat ook den brouwers in hun concurrentie met een buitenlandsch product werd tegemoetgekomen.

De betoogen der bakkers en grutters berustten feitelijk op tweeërlei grondslag: 10 dat zij de uitheemsche gist niet ontberen konden, omdat de brouwers buiten staat waren hen het heele jaar door van het noodige te voorzien, $2^{\circ}$ dat hun neringen en bijgevolg de gemeente zeer zouden worden gedrukt, wanneer de gist slechts tot exorbitant hoogen prijs te verkrijgen zou zijn. 't. Eerste argument nu was van geen kracht, daar de brouwers immers niet om een invoerverbod verzocht hadden. En wat het tweede betrof, dit gold niet wanneer kon worden bewezen, dat de prijs van de vreemde gist dien van de Hollandsche - welke aan bakkers en grutters bij de zetting op het brood en meel werd vergoed - niet zou te boven gaan. Gecommitteerde Raden nu gingen mee met het door de brouwers geleverde betoog, waarvan de conclusie was dat 1 pond droge buitengist altijd nog 5 stuivers goedkooper zou blijven dan $\frac{1}{2}$ ketel (Delftsche maat) of $\frac{1}{16}$ ton natte Hollandsche ${ }^{1}$ ): De werking van 1 ton natte gist stond gelijk met die van 16 pond droge, welke $16 \times 5$ stuivers of 4 gulden kostten, voor welk bedrag dus ook 1 ton natte buitengist moest zijn te krijgen; met de 8 gulden belasting erbij gevoegd werd dit 12 gulden, dat was nog 5 gulden 12 stuivers goedkooper dan 1 ton Hollandsche gist. Dat 1 pond droge buitengist niet meer dan $4 \frac{1}{2}$ à 5 st. kostte - hetgeen aan de heele berekening. ten grondslag lag werd nagenoeg door alle betrokkenen toegegeven.

Ten onrechte vreesden volgens Gecommitteerde Raden de bakkers en grutters, dat de brouwers den prijs van hun gist bovenmatig zouden opdrijven; die bleef immers ondanks de belasting toch nog hooger dan die van de buitengist. Een juiste conclusie, indien de gegevens, waarop de berekening was gebaseerd, inderdaad steeds in overeenstemming met de werkelijkhe d zijn geweest. Dat die vrees overdreven was, moet overigens worden toegegeven, De brouwers zouden immers altijd met de buitengist moeten blijven

1) Zie boven, blz. 401 . 
concureeren; om willekeurig den prijs daarvan te verhoogen - en dan nog slechte en vermengde gist te leveren, waarvoor bakkers en grutters van Brielle zich bezord makten ') was dus allerminst in hun eigen belang. Trouwens, Gecommitteerde Raden deden Hun Edel Groot Mogenden aan de hand om eventueel prijs en kwaliteit der gist vast te stellen in dier voege dat een Amsterdamsch mingelen gist, dat zes uur lang te bezinken had gestaan en waarvan het overtollige vocht was afgegoten, niet duurder dan tegen 15 stuivers zou mogen worden verkocht, en de minderé soorten naar evenredigheid, terwijl in de respectieve steden de magistraten, om te zorgen dat de kwaliteit op peil bleef, gezworen proevers zouden kunnen aanstellen. Onder deze beperking zouden Gecommitteerde Raden het verzoek der brouwers willen zien toegestaan.

Nadat den 23en April 1765 het ${ }^{-}$bovenbedoeld rapport ${ }^{2}$ ) door den raadpensionaris was uitgebracht, besloten Staten van Holland tot het.uitvaardigen van een publicatie, waarbij aan broodbakkers en alle anderen op verbeurte van 600 gulden werd verboden om "te maken of gebruiken eenige soorten van konstgist of konstdesem, toebereid uit mout, hoppe, alsem, tamerinde, suykeren, syropen, honig of andere speciën, hoe genaamt." Omtrent het al of niet belasten van de buitenlandsche gist bleven de beraadslagingen voortduren ${ }^{3}$ ).

Het conflict was dan nu, gedeeltelijk althans, in het voordeel der brouwers beslist. Hebben deze in hun strijd om hun gistmonopolie zooveel mogelijk te handhaven inderdaad het gelijk in die mate aan hun zijde gehad als Gecommitteerde Raden het zoowel in hun eerste advies ${ }^{4}$ ) als in hun bovengenoemd praeadvies willen doen uitkomen? Ik heb er reeds op gewezen, dat ten opzichte van hun vermogen om bakkers en grutters het geheele jaar door van de noodige gist te voorzien hun geweten toch niet volkomen zuiver schijnt te zijn geweest ${ }^{5}$ ). Meer dan éen

1) Zie boven, blz. 398 .

2) Zie blz. 411.

3) Resolutiën der Staten van Holland van 23 April 1765.

4) Zie boven, blz. 392-393.

5) Zie boven, blz. 408 . 
uitlating wijst daarop, b. v. deze, dat men; als een bepaalde brouwer geen gist leveren kan, die "doorgaans wel" in een andere brouwerij kan bekomen ${ }^{1}$ ).

Het lijkt ook inderdaad niet onwaarschijnlijk, dat bij het steeds in aantal afnemen der brouwerijen deze niet altijd de gistbehoeften der wassende bevolking hebben kunnen bevredigen. Stellig echter hebben de bakkers en grutters in hun begeerte om zich de goedkoopere gist in ruime mate te kunnen blijven verschaffen van hun kant sterk overdreven en gegeneralizeerd, terwijl men ook wel weer zal moeten aannemen dat de brouwers ondanks al hun verzekeringen van het tegendeel nu en dan met de gist - die zeker schaarscher is geweest dan zij willen erkennen - hebben geknoeid. Terwijl de vrees der bakkers en grutters, dat de brouwers, indien de belasting werd ingevoerd, al maar zouden doorgaan met den gistprijs te verhoogen, gerust ongegrond kan worden genoemd, schijnt toch een enkele uitlating der brouwers zelf erop te wijżen, dat zij met de prijsbepaling wel eens wat willekeurig hebben omgesprongen ${ }^{2}$ ). Of de beschuldiging der bakkers, dat de gistprijs sinds 40 à 50 jaar was verdubbeld, waarheid heeft bevat of integendeel de verzekering der brouwers, dat hij in dien tijd met $\frac{1}{3}$ was verminderd - helaas ontbreken ons positieve gegevens, die ons hieromtrent uitsluitsel. zouden kunnen verschaffen.

Intusschen hadden de beraadslagingen over een belasting op de uitheemsche gist geen voortgang. Nadat op de bijeenkomst der Generale Brouwers de zaak nu en dan nog eens ter sprake was gebracht, besloot. men in de vergadering van 7 Mei 1771 de gistcommissie te continueeren teneinde, zooals het werd uitgedrukt, het punt levendig te houden - waarmee de commissie echter geenerlei resultaat heeft bereikt, want een beschikking op de adressen der brouwers bleef uit.

Dr. E. M. A. Timmer.

(Wordt vervolgd).

I) Zie boven, blz. 401 .

2) Zie boven, blz. 403 . 